\title{
PROTOTIPE SISTEM KEAMANAN RUMAH MENGGUNAKAN KOMBINASI SENSOR DAN SMS GATEWAY
}

\author{
Fransiskus Panca Juniawan $^{1)}$, Dwi Yuny Sylfania ${ }^{2)}$
}

\author{
${ }^{1,2}$ Teknik Informasika, STMIK Atma Luhur \\ ${ }^{1,2}$ Jl. Jend. Sudirman, Selindung Baru, Pangkalpinang \\ Email: ${ }^{1}$ ransiskus.pj@atmaluhur.ac.id, ${ }^{2}$ dysylfania.atmaluhur.ac.id
}

\begin{abstract}
Abstrak
Keamanan rumah merupakan salah satu permasalahan dalam kehidupan sehari-hari. Kecemasan sering melanda disaat kita meninggalkan rumah. Namun, dengan penerapan sensor PIR yang dapat mendeteksi gerakan dan sensor magnetic switch yang dapat mendeteksi pintu yang terbuka, kita dapat mengetahui kemungkinan adanya penjahat yang masuk ke rumah. Selain itu fungsi SMS Gateway juga dapat dijadikan sebagai salah satu fitur untuk mengirimkan notifikasi pemberitahuan adanya gerakan dan status pintu yang terbuka kepada pemilik rumah. Penelitian ini bertujuan untuk membangun prototipe sistem keamanan rumah yang menggabungkan sensor PIR dan magnetic switch berbasis mikrokontroler dan SMS gateway. Metode yang digunakan adalah prototyping. Hasil pengujian sensor PIR dapat mendeteksi gerakan dengan jarak terjauh 5 meter, sedangkan sensor magnetic switch dapat mendeteksi pintu yang terbuka maksimal 2 centimeter. Notifikasi SMS juga berhasil dikirimkan kepada pemilik rumah setiap kali ada gerakan atau pintu yant terbuka yang terdeteksi oleh sensor.
\end{abstract}

Kata Kunci: Sistem Keamanan Rumah, Deteksi Gerakan, Mikrokontroler, SMS Gateway, Arduino

\section{Pendahuluan}

Semua orang pasti menginginkan rumah yang aman dari segala tindak kejahatan. Rumah bukan hanya berfungsi sebagai tempat berteduh dan beristirahat, namun di dalamnya pasti tersimpan barang-barang yang berharga. Oleh karena itu keamanan rumah menjadi salah satu tantangan bagi pemilik rumah.

Berdasar data dari Badan Pusat Statistik [1], pada tahun 2017 terdapat 107.042 kasus kejahatan di Indonesia terhadap hak/milik tanpa penggunaan kekerasan. Demikian juga dengan kejahatan di Provinsi Kepulauan Bangka Belitung dengan angka 739 kasus [1]. Melihat angka-angka ini, maka dapat disimpulkan bahwa tindak pencurian pada rumah-rumah masyarakat masih tergolong tinggi.

Perkembangan teknologi saat ini dapat diterapkan sebagai sistem keamanan rumah. Telah ada banyak sensor yang dapat digunakan untuk mendeteksi tindak kejahatan. Diantaranya dengan menggunakan sensor PIR
(Passive Infra Red) yang dapat mendeteksi adanya gerakan, dan juga sensor magnetic switch yang dapat mendeteksi terbukanya pintu rumah. Selain itu sebagai sistem notifikasi terhadap pemiliki rumah dapat menggunakan modul GSM. Kedua sensor dan modul GSM dipasang dalam sebuah antarmuka mikrokontroler berbasis Arduino sehingga dapat bekerja secara maksimal.

Telah banyak penelitian sebelumnya yang melakukan pengembangan terhadap sistem keamanan rumah. Sensor PIR telah digunakan sebagai pendeteksi gerakan pada sistem keamanan yang diterapkan pada rumah [2]-[3] dan juga ruangan arsip [4]. Bentuk pengamanan lainnya diterapkan pada pintu rumah yang juga dapat dilakukan dengan menggunakan mikrokontroler [5] dan SMS sebagai notifikasi kepada pemilik [6]-[7].

Dilakukan juga pengembangan sistem keamanan rumah berbasis GSM dengan memanfaatkan fitur SMS sebagai bentuk notifikasinya [8]-[9]-[10]-[11]. Selain itu telah dilakukan penelitian mengenai smarthome atau rumah pintar yang berbasis multisensor [12]-[13], kemudian juga dilakukan penelitian mengenai smarthome yang berbasis wireless dengan menggunakan fuzzy logic sebagai pengaturan wireless tersebut [14]. Smarthome juga dapat dikembangkan dengan menggunakan antarmuka kepada pengguna menggunakan web [15]-[16], dan yang berbasis android [17]. Selain itu juga dikembangkan gedung pintar energi (smartbuilding) yang berbasis multisensor [18].

Selain itu mikrokontroler juga dapat diterapkan pada berbagai bidang lainnya, yakni sebagai alat kontrol penggunaan energi pada gedung [19], alat pelacak lokasi sebagai bentuk antisipasi penculikan anak [20], peringatan jarak aman antar kendaraan [21], media kendali jarak jauh berbasis android [22], dan sebagai penjemur pakaian otomatis [23].

Dari berbagai penelitian yang telah dilakukan sebelumnya, maka diusulkan penerapan penggunaan sensor PIR dan magnetic switch pada pintu sebagai sistem keamanan rumah. Dilengkapi juga buzzer dan notifikasi menggunakan modul GSM untuk mengirimkan SMS kepada pemilik rumah.

\section{Metode Penelitian}

Penelitian ini menggunakan metode prototyping dengan 
empat tahapan utama yang ditampilkan seperti pada Gambar 1. Tahapan yang dilakukan adalah pengumpulan data, perencanaan cepat, perancangan prototype, dan pengujian prototype.

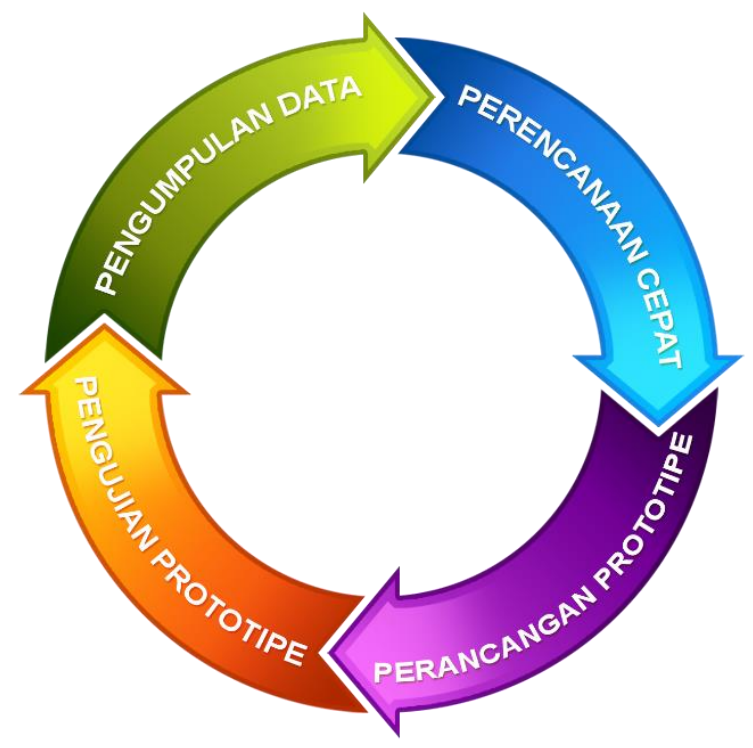

Gambar 1. Tahapan Penelitian

\subsection{Tahapan Pengumpulan Data}

Tahapan ini melakukan pengumpulan data yang dibutuhkan untuk pelaksanaan penelitian ini, diantaranya studi literatur dan observasi terhadap kebutuhan keamanan rumah. Selain itu juga dilakukan analisa kebutuhan perangkat keras dan perangkat lunak sistem. Adapun kebutuhan perangkat kerasnya adalah sebagai berikut:

1) Notebook

2) Mikrokontroler Arduino Atmega 328

3) Sensor PIR

4) Sensor Magnetic Switch

5) Buzzer

6) Modul GSM Shield

Sedangkan kebutuhan perangkat lunaknya adalah sebagai berikut:

1) Arduino IDE

2) Fritzing

3) Astah Community

\subsection{Tahapan Perencanaan Cepat}

Pada tahapan perencanaan cepat dilakukan perancangan sistem yang akan dibangun berdasarkan hasil dari pengumpulan data dan kebutuhan. Hasil dari perancangan berupa usecase diagram, package diagram, dan deployment diagram.

\section{A. Activity Diagram}

Activity diagram dibuat untuk menggambarkan alur proses keseluruhan dari sistem keamanan yang dibuat. Perancangan dibagi menjadi tiga bagian, yakni input, proses, dan output.
1. Rancangan Input

Rancangan ini memberikan penjelasan mengenai alur masukan (input) dari sistem keamanan yang dibangun. Adanya gerakan yang dideteksi oleh sensor PIR maupun status pintu terbuka yang dideteksi oleh sensor magnetic switch kemudian dikirimkan ke input pin untuk kemudian diteruskan ke Arduino untuk dieksekusi.

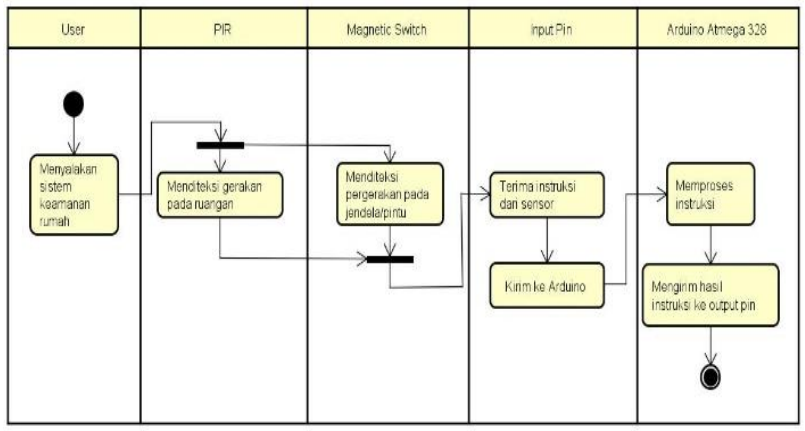

Gambar 2. Rancangan Input Sistem

\section{Rancangan Proses}

Rancangan ini memberikan penjelasan mengenai alur proses dari sistem keamanan yang dibangun. Rangkaian proses dilakukan pada input pin dan dieksekusi oleh mikrokontroler Arduino Atmega 328. Dan barulah hasil instruksi dikirimkan oleh pin output.

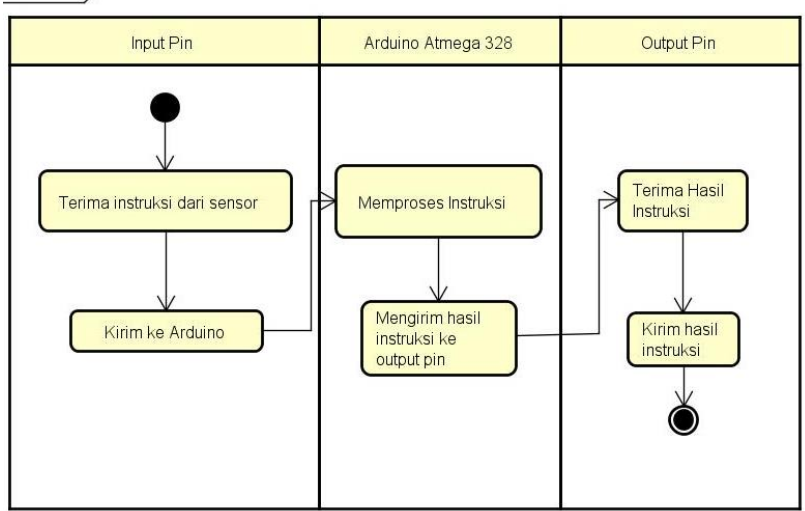

Gambar 3. Rancangan Proses Sistem

\section{Rancangan Output}

Rancangan ini memberikan penjelasan mengenai alur hasil keluaran (output) dari sistem keamanan yang dibangun. Dimulai dari arduino yang memproses instruksi, kemudian mengirim hasil tersebut ke output pin, dan dieksekusi oleh buzzer dan modul GSM.

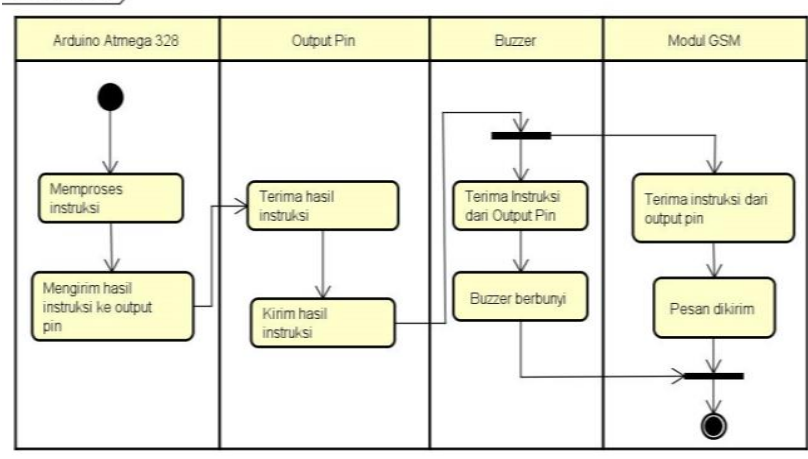

Gambar 4. Rancangan Output Sistem 
B. Deployment Diagram

Diagram ini bertujuan untuk menampilkan arsitektur sistem dan hubungan antar komponen yang digunakan dalam sistem.

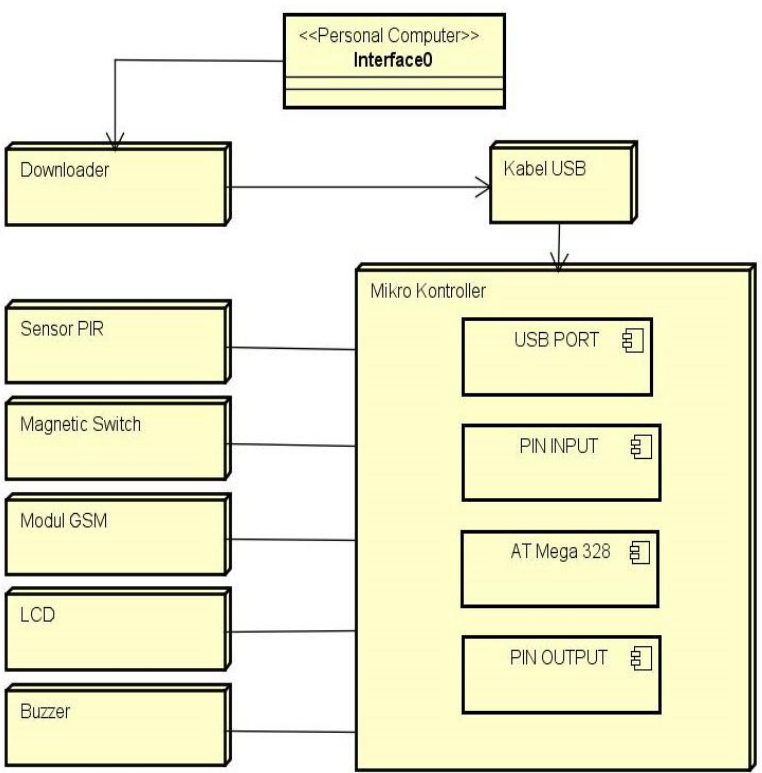

Gambar 5. Deployment Diagram

\subsection{Tahapan Perancangan Prototipe}

Setelah dibuat perancangan cepat ditentukan, maka hasil perancangan tersebut diimplementasikan dalam bentuk prototipe. Gambar 6 adalah gambaran rancangan fisik dari komponen perangkat keras sistem keamanan yang dibangun.

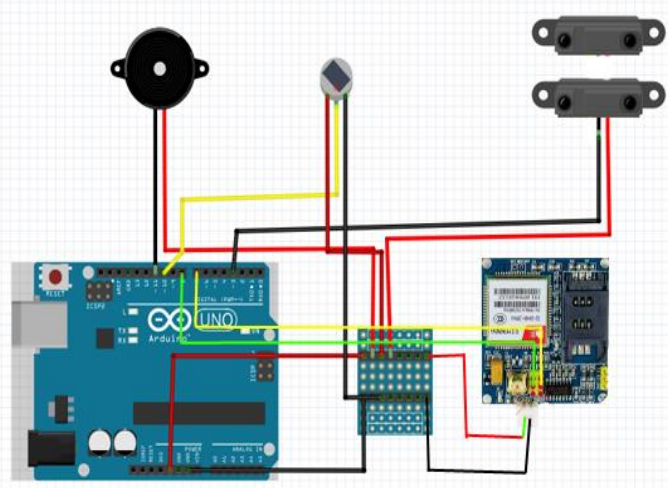

Gambar 6. Rancangan Fisik Perangkat Keras

\subsection{Tahapan Pengujian Prototipe}

Tahap terakhir adalah melakukan beberapa pengujian terhadap prototipe untuk mengetahui kinerjanya.

\section{Hasil dan Pembahasan}

\subsection{Implementasi}

Dalam pelaksanaan penerapan prototipe, dibuat simulasi rumah yang menggunakan bahan dasar kayu. Hal ini untuk mempermudah pembangunan dan penerapan sistem. Digunakan juga sensor PIR, sensor magnetic switch, Buzzer, Modul GSM Shield, dan Arduino ATMega 328

\section{A. Magnetic Switch}

Sensor magnetic switch memiliki dua bagian yang diletakkan di pintu (disesuaikan dengan kondisi pintu). Pada simulasi menggunakan pintu dengan model kiri dan kanan. Bagian pertama sensor diletakkan pada pintu sebelah kiri, dan bagian kedua diletakkan pada pintu sebelah kanan. Apabila kedua pintu terbuka, secara tidak langsung maka kedua bagian sensor yang awalnya menempel akan terlepas. Hal ini akan memicu magnetic yang ada pada sensor untuk bereaksi terhadap pintu yang terbuka dan dianggap bahwa pintu dalam status terbuka.

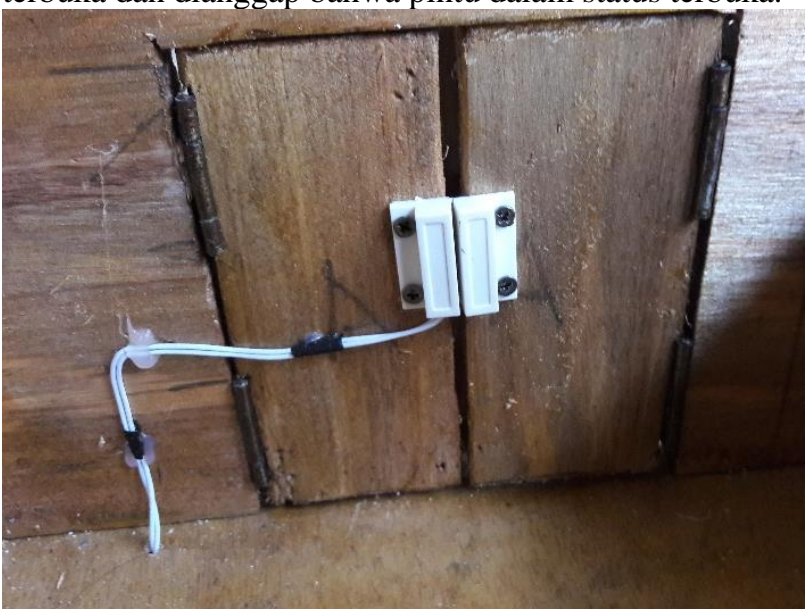

Gambar 7. Sensor Magnetic Switch

\section{B. Sensor PIR (Passive Infra Red)}

Sensor PIR merupakan piranti Pyroelectric yang melakukan deteksi gerakan dengan melakukan pengukuran adanya perubahan tingkat radiasi inframerah yang dipancarkan oleh objek-objek yang berada di sekitarnya [2]. Pada simulasi, sensor diletakkan pada sudut dinding dengan tujuan untuk memperluas jangkauan deteksi sensor sehingga dapat menangkap gerakan lebih jauh.

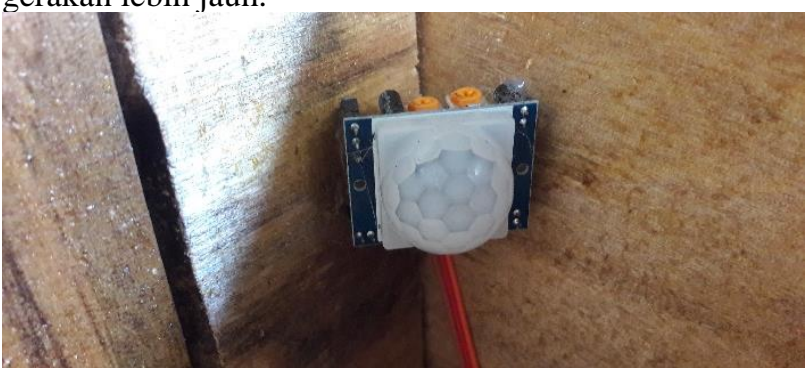

Gambar 8. Sensor PIR

\section{Buzzer}

Buzzer adalah sebuah komponen elektronika yang berfungsi untuk mengubah getaran listrik menjadi getaran suara [24]. Secara umum prinsip kerjanya hampir sama dengan loud speaker kumparan yang terpasang pada diafragma dan kemudian kumparan tersebut dialiri arus sehingga menjadi elektromagnet. 


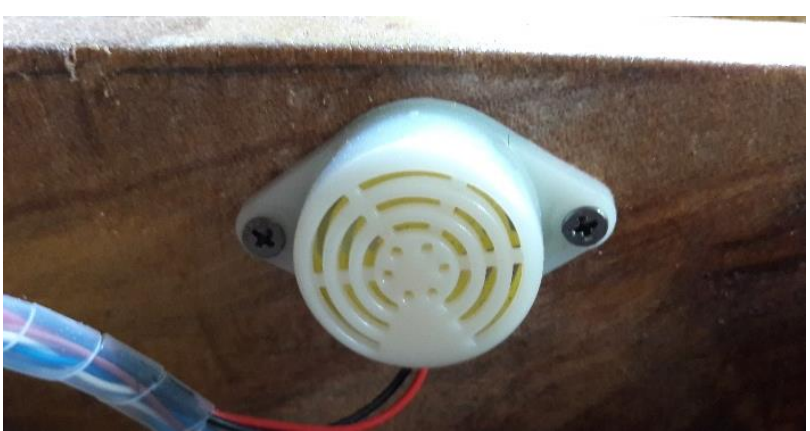

Gambar 9. Buzzer

\section{Modul GSM Shield}

Modul GSM berguna untuk mengirimkan pesan notifikasi berupa pesan text SMS (Short Message Service) saat sensor membaca gerakan. Modul GSM terdiri dari 4 Pin yang terdiri dari RX, TX, Vcc, dan Ground.

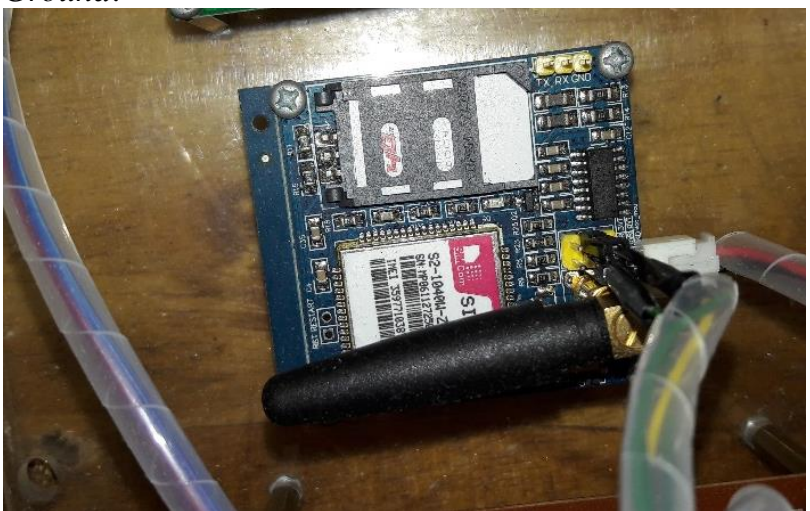

Gambar 10. Modul GSM Shield

E. Rangkaian Keseluruhan

Gambar 11 merupakan tampilan dari keseluruhan rangkaian sistem keamanan rumah yang dibangun.

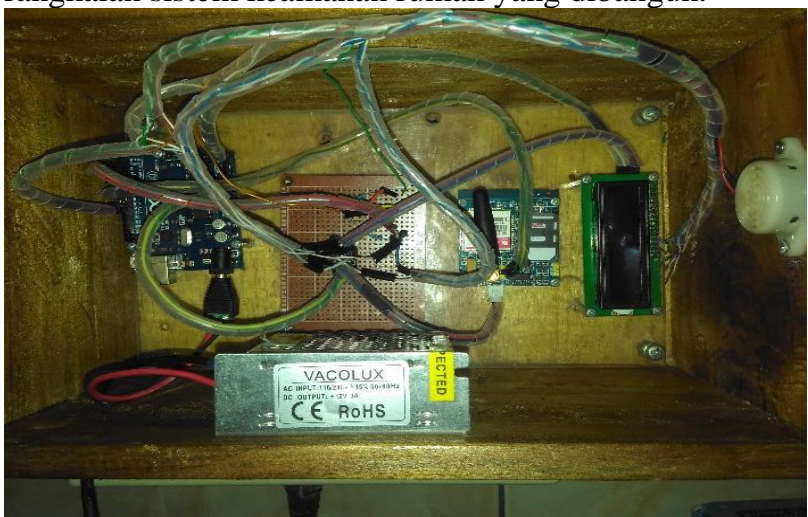

Gambar 11. Tampilan Rangkaian Keseluruhan

\subsection{Pengujian}

Tahap pengujian yang dilakukan adalah pengujian deteksi gerak pada sensor PIR dan deteksi status pintu yang terbuka dengan magnetic switch. Selain itu hasil pengujian buzzer dan pengiriman SMS pada GSM Shield juga secara tidak langsung didapatkan.

A. Pengujian Sensor PIR

Pengujian ini bertujuan untuk mengetahui kinerja dari sensor PIR dalam melakukan pendeteksian gerakan. Tabel 1 merupakan hasil dari pengujian ini.
Tabel 1. Pengujian Sensor PIR

\begin{tabular}{|c|c|c|c|c|}
\hline No. & Jarak & $\begin{array}{l}\text { Sensor } \\
\text { PIR }\end{array}$ & Buzzer & $\begin{array}{c}\text { GSM } \\
\text { Shield } \\
\end{array}$ \\
\hline 1 & 1 meter & Deteksi & Berbunyi & $\begin{array}{l}\text { SMS } \\
\text { dikirim }\end{array}$ \\
\hline 2 & 2 meter & Deteksi & Berbunyi & $\begin{array}{l}\text { SMS } \\
\text { dikirim }\end{array}$ \\
\hline 3 & 3 meter & Deteksi & Berbunyi & $\begin{array}{l}\text { SMS } \\
\text { dikirim }\end{array}$ \\
\hline 4 & 4 meter & Deteksi & Berbunyi & $\begin{array}{l}\text { SMS } \\
\text { dikirim }\end{array}$ \\
\hline 5 & 5 meter & Deteksi & Berbunyi & $\begin{array}{l}\text { SMS } \\
\text { dikirim }\end{array}$ \\
\hline 6 & 5,1 meter & $\begin{array}{l}\text { Tak } \\
\text { Terdeteksi }\end{array}$ & $\begin{array}{l}\text { Tidak } \\
\text { Berbnyi }\end{array}$ & $\begin{array}{l}\text { SMS } \\
\text { tidak } \\
\text { dikirim }\end{array}$ \\
\hline
\end{tabular}

B. Pengujian Sensor Magnetic Switch

Pengujian ini untuk mengetahui kinerja dan seberapa jauh jarak maksimal yang dapat dideteksi oleh sensor saat pintu atau jendela terbuka. Hasil pengujian dijabarkan pada Tabel 2 .

Tabel 2. Pengujian Magnetic Switch

\begin{tabular}{lcccl}
\hline No. & Jarak & $\begin{array}{c}\text { Magnetic } \\
\text { Switch }\end{array}$ & Buzzer & $\begin{array}{l}\text { GSM } \\
\text { Shield }\end{array}$ \\
\hline 1 & $1 \mathrm{~cm}$ & Deteksi & Berbunyi & $\begin{array}{l}\text { SMS } \\
\text { dikirim }\end{array}$ \\
2 & $1,5 \mathrm{~cm}$ & Deteksi & Berbunyi & $\begin{array}{l}\text { SMS } \\
\text { dikirim }\end{array}$ \\
3 & $1,9 \mathrm{~cm}$ & Deteksi & Berbunyi & $\begin{array}{l}\text { SMS } \\
\text { dikirim }\end{array}$ \\
4 & $2 \mathrm{~cm}$ & Tak & Tidak & $\begin{array}{l}\text { SMS } \\
\text { tidak } \\
\text { dikirim }\end{array}$ \\
& & Terdeteksi & Berbunyi & \\
& & & &
\end{tabular}

\section{Tampilan SMS Notifikasi}

Gambar 12 menunjukkan tampilan SMS dengan kondisi pintu terbuka, sedangkan Gambar 13 menunjukkan tampilan SMS dengan kondisi jendela yang terbuka. Gambar 14 menunjukkan tampilan notifikasi SMS dengan kondisi terdeteksi adanya gerakan oleh sensor PIR.

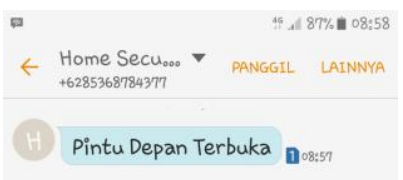

Gambar 12. Tampilan SMS Pintu Depan Terbuka 


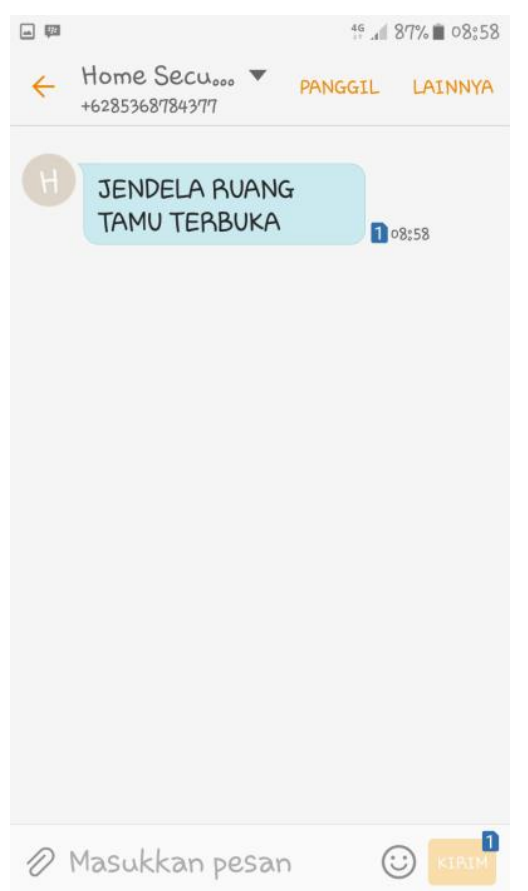

Gambar 13. Tampilan SMS Jendela Depan Terbuka

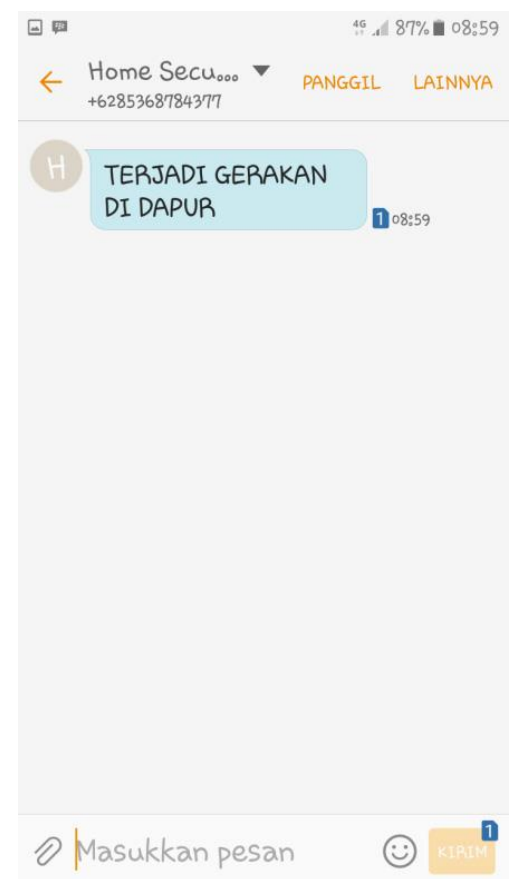

Gambar 14. Tampilan SMS Deteksi Gerakan

\section{Kesimpulan}

Kombinasi sensor PIR dan magnetic switch dapat diterapkan pada sistem keamanan rumah. Dengan menambahkan Buzzer dan fungsi SMS menggunakan modul GSM maka pemilik rumah dapat diberikan notifikasi berisi informasi adanya gerakan di dekat sesor, ataupun status pintu yang terbuka.

Dari hasil pengujian sensor PIR didapat hasil bahwa jarak terjauh sensor untuk mendeteksi gerakan adalah sejauh 5 meter. Sedangkan jarak terjauh magnetic switch mendeteksi pintu yang terbuka adalah 2 centimeter. Selain itu buzzer selalu berbunyi jika terdeteksi gerakan atau jika pintu dan jendela terbuka. Notifikasi SMS pun juga bekerja sesuai fungsinya. Pada saat terdeteksi gerakan dan pintu/jendela terbuka, maka modul GSM berhasil mengirimkan SMS ke pemilik rumah.

\section{Daftar Pustaka}

[1] B. Statistik Badan Pusat, "Statistik Kriminal 2018," Badan Pusat Statistik, Jakarta, 2018.

[2] J. Waworundeng, L. D. Irawan, and C. A. Pangalila, "Implementasi Sensor PIR sebagai Pendeteksi Gerakan untuk Sistem Keamanan Rumah menggunakan Platform IoT," Cogito Smart Journal, vol. 3, no. 2, pp. 152-163, 2017.

[3] A. Mubarok, I. Sofyan, A. A. Rismayadi, and I. Najiyah, "Sistem Keamanan Rumah Menggunakan RFID , Sensor PIR dan Modul GSM Berbasis Mikrokontroler," Jurnal Informatika, vol. 5, no. 1, pp. 137-144, 2018.

[4] F. P. Juniawan, D. Y. Sylfania, and E. A. Dika, "Prototipe Sistem Keamanan Ruangan Arsip Menggunakan Mikrokontroler Berbasis SMS Gateway," in Konferensi Nasional Sistem Informasi, 2018, pp. 1042-1047.

[5] M. Bimo, B. Setiyono, and A. Sofwan, "PERANCANGAN DOOR LOCK SYSTEM PADA SMART HOME MENGGUNAKAN MIKROKONTROLLER ATMEGA16 BERPLATFORM ANDROID," Transient, vol. 6, no. 4, pp. 575-581, 2017.

[6] M. R. Asad, O. D. Nurhayati, and E. D. Widianto, "Sistem Pengamanan Pintu Rumah Otomatis Via SMS Berbasis Mikrokontroler ATMega328P," Jurnal Teknologi dan Sistem Komputer, vol. 3, no. 1, pp. 1-7, 2015.

[7] D. Widcaksono and M. Masyhadi, "RANCANG BANGUN SECURED DOOR AUTOMATIC SYSTEM UNTUK KEAMANAN RUMAH MENGGUNAKAN SMS BERBASIS ARDUINO," Jurnal Kajian Teknik Elektro, vol. 3, no. 1, pp. 5266, 2018.

[8] E. Isa and N. Sklavos, "Smart Home Automation: GSM Security System Design \& Implementation," Journal of Engineering Science and Technology Review, vol. 10, no. 3, pp. 170-174, 2017.

[9] H. N. Awl and B. A. Karim, "Smart Home System Based on GSM Network," Kurdistan Journal of Applied Research, vol. 3, no. 1, pp. 17-21, 2018.

[10] N. H. Saleh, B. A. Mubdir, A. M. Al-Hindawi, and A. H. Ahmed, "Design and Implementation of Smart Home Energy Management System Based on GSM Network," Kurdistan Journal of Appled Reserch, vol. 2, no. 3, 2017.

[11] A. S. Ramadhan and L. B. Handoko, "RANCANG BANGUN SISTEM KEAMANAN RUMAH BERBASIS ARDUINO MEGA 2560," Techo.COM, vol. 15, no. 2, pp. 117-124, 2016. 
[12] Y. Hsu et al., "Design and Implementation of a Smart Home System Using Multisensor Data Fusion Technology," Journal Sensors, vol. 17, no. 1631, pp. 1-21, 2017.

[13] D. Kurnianto, A. M. Hadi, and E. Wahyudi, "PERANCANGAN SISTEM KENDALI OTOMATIS PADA SMART HOME MENGGUNAKAN MODUL ARDUINO UNO," Jurnal Nasional Teknik Elektro, vol. 5, no. 2, pp. 260-270, 2016.

[14] D. Desmira and D. Aribowo, "PERANCANGAN SMARTHOME DENGAN RASBERRY BERBASIS WIRELESS MENGGUNAKAN MICROKONTOLLER AVR ATMEGA328 DAN FUZZY LOGIC," Jurnal Simetris, vol. 7, no. 2, pp. 707-716, 2016.

[15] F. Masykur and F. Prasetiyowati, "APLIKASI RUMAH PINTAR ( SMART HOME ) PENGENDALI PERALATAN ELEKTRONIK RUMAH TANGGA BERBASIS WEB," Jurnal Teknologi Informasi dan Ilmu Komputer, vol. 3, no. 1, pp. 51-58, 2016.

[16] M. Muharam, M. Latif, and M. Saputra, "SISTEM KENDALI JARAK JAUH BERBASIS WEB UNTUK SISTEM RUMAH PINTAR," Jurnal Naional Teknik Elektro, vol. 7, no. 3, pp. 203-208, 2018.

[17] D. Yendri and R. E. Putri, "Sistem Pengontrolan Dan Keamanan Rumah Pintar ( Smart Home ) Berbasis Android," Journal of Information Technology and Computer Engineering, vol. 2, no. 1, pp. 1-6, 2018.

[18] B. Usmanto and T. Susilowati, "PERANCANGAN PROTOTYPE TEKNOLOGI SMART BUILDING MENGGUNAKAN ARDUINO BERBASIS WEB
PROPINSI LAMPUNG MENUJU PROGRAM LAMPUNG SMART CITY," Jurnal Informatika, vol. 17 , no. 2 , pp. 45-53, 2017.

[19] C. Chen, C. Liu, C. Kuo, and C. Yang, "Web-Based Remote Control of a Building 's Electrical Power, Green Power Generation and Environmental System Using a Distributive Microcontroller," Journal Mircomachines, vol. 8, no. 241, pp. 1-12, 2017.

[20] Z. Sembiring and R. Muliono, "Perancangan Alat Pelacak Lokasi Dalam Mengantisipasi Penculikan Anak," Techo.COM, vol. 18, no. 1, pp. 13-25, 2019.

[21] R. Mardiati, F. Ashadi, and G. F. Sugihara, "Rancang Bangun Prototipe Sistem Peringatan Jarak Aman pada Kendaraan Roda Empat Berbasis Mikrokontroler ATMEGA32," Jurnal TELKA, vol. 2, no. 1, pp. 53-61, 2016.

[22] S. Samsugi and D. Kastutara, "ARDUINO DAN MODUL WIFI ESP8266 SEBAGAI MEDIA KENDALI JARAK JAUH DENGAN ANTARMUKA BERBASIS ANDROID," Teknoinfo, vol. 12, no. 1, pp. 23-27, 2018.

[23] N. S. Yogaswara, G. F. Gunawan, and F. E. Purwiantono, "PROTOTYPE PENJEMUR PAKAIAN OTOMATIS BERBASIS MICROCONTROLLER ARDUINO DENGAN METODE NAÏVE BAYES SERTA MENGGUNAKAN SENSOR LDR DAN SENSOR KELEMBABAN," Teknoinfo, vol. 13, no. 1, pp. 29-35, 2019.

[24] A. Kadir, From Zero to A Pro: Arduino, 1st ed. Yogyakarta: Andi Publisher, 2015. 